\title{
Mechanisms of Interaction of the State and Civil Society in the Sphere of Anti-corruption Activity in the Light of Implementation of Article 13 of the UN Convention against Corruption in the Russian Legislation
}

\author{
Andrey V. Putintsev and Tuiana Ch. Sharakshinova* \\ Baikal State University \\ 11 Lenin Str., Irkutsk, 664003, Russia
}

Received 26.10.2015, received in revised form 08.12.2015, accepted 14.01.2016

The article analyzes a mechanism of interaction of the state and civil society in the process of implementation of Article 13 of the UN Convention against Corruption. The authors study some trends of the legal regulation in the anti-corruption sphere and anti-corruption initiatives of civil society. The article proposes ways to increase the efficiency of implementation of standards of Article 13 of the UN Convention against Corruption into the Russian Legislation.

Keywords: corruption, civil society, transparency, protection of informants in corruption cases.

DOI: 10.17516/1997-1370-2016-9-2-510-516.

Research area: law.

\section{Introduction \\ into the problem.}

In accordance with the UN Convention against Corruption adopted in 2003, the State party undertakes to establish and maintain an effective, coordinated anti-corruption policy (United Nations..., 2003). Measures for the implementation of international standards on combating corruption in the national law of the state are determined independently. By the legal nature the norm of Art.13 of the UN Convention against Corruption is the principle of prevention, however, the legal wordings that are not enough verified make it declarative, depriving it of clearance and certain content. There are two factors that limit the scope of implementation of this article in the national legislation of the contracting parties of the Convention: the fundamental principles of legislation and opportunities of the contracting parties of the Convention. The wording of the Convention "within its opportunities" unlikely can be considered successful, because it is not imperative. It is also not clear which opportunities - organizational, financial, cultural and political - we are talking about.

(C) Siberian Federal University. All rights reserved

* Corresponding author E-mail address: chiefdom@yandex.ru, tuyana.91@mail.ru 
The list of measures aimed at implementing the provisions of the Convention cannot be considered exhaustive.

Implementation of the provisions of Article 13 of the UN Convention against Corruption is not confined to the reproduction of its provisions in the national legislation. It requires a mechanism of the civil society participation in the fight against corruption, and this mechanism should get legal consolidation. The mechanism should be based on objective possibilities of the State and the reached level of development of civil society.

\section{Methodology}

In the course of the study we applied logic, comparative-legal, formal-legal methods, and in the analysis of Internet resources of the civil society institutions we used a method of content analysis.

\section{Discussion}

In accordance with the international obligations, the state should provide citizens with the means to prevent and to take action against corruption, including the freedom to seek, receive, publish and disseminate information concerning corruption. Anti-corruption activity should not be limited to reporting on corruption. In order to investigate the corrupt activity, to identify and trace the proceeds of corruption, citizens must have access to all relevant information, subject only to those restrictions that are necessary in a democratic society (Efimov, 2011). The general public should also have access to the channels of anonymous communication.

Experts rightly point out the low level of implementation of the principle (Schedrin, 2013, p. 281). Conditions for the active participation of the civil society institutions in the fight against corruption are created only in a declarative calling plan (Okhotskiy, 2012, p. 91). The practical implementation of the principle requires solving a number of problems, the existence of which is noted in the official documents in particular (The concept of interaction..., 2016). According to the experts, the problems are not completely resolved (Rogovaia, 2013. p. 22). The corruption informants need protection; an independent anticorruption expertise should be given a special status; substantial revision of the legislation on the publication of information on officials' incomes and expenditures is required as well.

\section{Practice of the civil society institutions}

According to the analysis of policy documents of public anti-corruption organizations, most of them have finished plans of cooperation with public authorities. One of the main areas of cooperation is considered to be the development of proposals of a law-making character in the fight against corruption. This area can also include an independent anti-corruption expertise (The Federal..., p. 5). However, the publication of reports on the effectiveness of such an expertise by both the experts and the law-making bodies is an exception rather than a rule (Anti-corruption..., January 23, 2016), (Anti-corruption..., January 10, 2016).

The second main area of activity of noncommercial organizations is drawing up various analytical reviews and reports. The research capacity of the specialized anti-corruption institutions is sufficiently large. However, these reports should be drawn up taking into account the recipient's sense of justice, and a document addressed to the public authorities should be clear to a mass audience. In some countries, this kind of information in specific areas is available to concerned citizens. For example, the experience of openness in the field of school education is analyzed by V.V. Tereshkova (Tereshkova, 2015, p. 267).

The third area of activity is of informational and propagandistic character: public lectures, 
competitions for the best journalistic material on anti-corruption, etc. It is noteworthy to mention a project "Transparency International", "Declarator" (Declarator, January 23, 2016) that is a large database combining together the income declarations submitted on various websites of public authorities, which partially solves a problem of lack of such a state portal.

The fourth area of activity is the work with the applications of citizens on corruption cases and their transfer to the competent state bodies and control over their consideration.

\section{The need to consolidate}

the efforts of civil society

It should be noted that the consolidation of the civil society institutions is among the objectives of most of the organizations. In society, there is no single ideological platform to combine the anticorruption efforts. The civil society institutions have different views on anti-corruption activities. Some organizations focus on integration with the government and support of its initiatives, others seek to consolidate the efforts of the entire private sector, while others are set to lobbying their initiatives in the public authorities and having a public control over them.

A weak degree of coordination between the institutions of civil society leads to various forms of realization of the need to fight against corruption, including the unconventional ones (Efimov, 2011, p. 189). Some of these practices are noteworthy. Thus, the project "RosPil" ("RosPil"..., January 23, 2016) funded by private donations, in fact, is acting under the scheme of social movement. According to the organizer of the project A. Navalnyi, movement registration in any form will create a basis for the state control, which largely can be avoided by staying outside a specific organizational and legal form (Navalnyi..., January 23, 2016). According to the analysis of materials from the web-site of the
"RosPil" project, the procedural cooperation of the "RosPil" project with the law enforcement agencies is carried out on behalf of A. Navalnyi. Thus, using small personal and financial contributions of a large number of people, the "RosPil" project frees them from the need to have personal interaction with the public authorities acting by a qualified mediator. A similar project "For honest procurements" was launched on September 1, 2013 by the All-Russia People's Front. ("For honest procurement", January 23, 2016).

Two anti-corruption activity discourses of civil society.

Anti-corruption measures are taken by the civil society in two directions: formally and informally institutionalized. The formally institutionalized direction includes the specialized anti-corruption organizations and general organizations having interest in anti-corruption.

Conditionally, there are two competing discourses, within which the anti-corruption activities of civil society are being developed: conditionally oppositional and conditionally loyalistic. Supporters of the oppositional discourse believe that corruption is only a part of the global problems of Russia. They believe that they can interfere in the activities of the authorities using political and information means and carry out public control on their own. This area is represented by informal movements and political parties, and by a number of mass media (Baksheev, 2016), (The first anti-corruption..., 2016), (Russian Political..., 2016).

Neutrality of political views dominates in the conditionally loyalistic direction. Corruption is seen in isolation from the many other problems. Local reformation steps are largely proposed in combating corruption. The idea of the maximum consolidation of institutions of the civil society (including the private sector) and the state is dominant in 
the fight against corruption. Non-legal means of pressure on the government are largely excluded. (To a question..., 2016) In this direction, self-regulatory organizations, trade unions, etc. operate.

In our opinion, different views on the nature of corruption and various political interests of the institutions of the civil society characterize the degree of maturity of a society. It is absolutely wrong to seek artificial neutrality, to intervene in the functioning of the civil society. A more effective method is a scheme of platforms for discussions of various forces that would create a system of checks and balances in the very civil society, in order to eliminate corruption manifestations within it.

In our view, the concept of specialization of the civil society institutions looks promising. The concept of specialized anti-corruption organizations, in our opinion, is not sufficiently effective without fight against corruption by the public organizations dealing with other issues (Burchuladze, 2012, p. 39).

\section{Conclusion}

We have made recommendations to improve the effectiveness of the implementation of Article 13 of the UN Convention against Corruption.

Firstly, it is necessary to establish a mechanism of cooperation with the state, which will be transparent for the civil society, will have a legal form, and will provide coordination of the activity of the state and society at all stages of anticorruption activities (Kabanov, 2012, p. 5 - 6). This mechanism should be universal, applicable for implementation at all levels of the state power and open to the voluntary participation of all subjects concerned.

The most obvious mechanism would be creation of coordinating bodies at all levels of the public authorities that would comprise public authorities, local government and civil society institutions, which would contribute to the development of informed decisions in the anticorruption field and ensure effective information interaction. The creation of such bodies will be a precondition not only for the integration of the civil society institutions and the state, but also for the consolidation of the very civil society. Establishing coordinating bodies is provided for by the anti-corruption legislation, there are certain doctrinal proposals (Krasnousov, 2011), but the role of the civil society institutions in the creation and interaction with such bodies is not clear.

Secondly, the institution of an anti-corruption independent expertise of regulatory legal acts requires improvement. In its current form, an independent anti-corruption expertise has little to do with the implementation of mechanisms of the state's responsibility to society. First of all, the accreditation system of potential independent experts draws criticism. On the one hand, a notification procedure for accreditation does not create insurmountable barriers to potential experts. However, the absence of requirements to legal literacy of an expert has negative consequences. The Federal Law No. 172- FZ dated July 17, 2009 "On the Anti-corruption Expertise of Regulatory Legal Acts and Draft Regulatory Legal Acts" (The Federal Law..., 2009) does not establish any order of consideration for the conclusion of an independent expertise, which, in fact, is different from the general order of consideration of public appeals. It seems logical either to refuse accreditation that actually conveys a solely statistical meaning, or to legally approve a special procedure for the consideration of proposals, by adding the article "Guarantees for recording a conclusion of an independent anticorruption expertise" to the Federal Law No. 172FZ. The article should ensure a judicial protection of an expert, set a reduced term of consideration of applications, the right to apply in a general 
manner, provide the applicant an opportunity to participate in the consideration of its conclusion in the legislative process. This will lead to the interaction of a prosecutor's office and judicial bodies with independent experts in the field of public relations regulated by a verifiable act.

Thirdly, particular attention should be paid to the order of submission of allegations of corruption to the public authorities. We propose to establish mechanisms for mediation between the applicant who is not familiar with the public administration system and the public authorities by supporting non-governmental organizations involved in admission of applications from people. This will protect the applicants and ensure their confidentiality for the public authorities, which, at the same time, will eliminate anonymity because responsibility will remain on the organization that actually submitted the application. The activities of these organizations must be based on the principle of professionalism and proficiency, legal support of the application at all stages of its review, obligation to transfer the information received. This procedure will help to avoid fears expressed by experts about the abuse of public allegations against officials from public figures (Samarucha, 2015, p. 65). An option could be a mechanism of accreditation of such organizations in the Ministry of Justice of the Russian Federation. These organizations should have the right to request a report from the law enforcement agencies on the review of applications. Implementation of the proposed model will realize the provisions of the $P$. 2 of Art.13 of the UN Convention against Corruption.

It is also necessary to revise the system of transparency of the public authorities. It seems reasonable to create a single state portal that is functionally identical to the "Declarator", which would demonstrate anti-corruption declarations of officials by geographical and hierarchical features. A stimulation system for activities of organizations also needs to be reformed. Considering international practices, it seems reasonable to take into account the private interests of the applicants and their stimulation with percentage of the amount returned to the budget. The literature analyzes foreign experience of such mechanisms (Khlonova, 2013, p. 273, 276). In our view, it is necessary to establish certain preferences for organizations that demonstrate high standards of anti-corruption activities.

The provisions of Article 13 of the UN Convention against Corruption as international obligations should be performed in good faith taking into account the real possibilities of the state and the state of civil society. Implementation of the provisions of Article 13 of the UN Convention against Corruption into the Russian law requires harmonization of efforts of the state "from above" and social initiatives "from below", which is impossible without willingness of social forces to hear each other.

\section{References}

Anti-corruption expertise of draft laws (2015), Available at: http://www.irk.gov.ru/law/ekspertiza zakonov/ (accessed on January 23, 2016).

Anti-corruption expertise of legal acts. (2015), Available at: http://www.ak-center.ru/legal/ expertise/ (accessed on January 10, 2016).

Baksheev, M. Threat to national security: an interview with A. Belyakov. In newspaper "Tribuna". Available at: http://www.stopcorruption.ru/item_1039.htm (accessed on January 23, 2016).

Burchuladze, M. (2012) Institutions of civil society against corruption. In Observer, (11), 34-44. 
The concept of interaction between the government, local authorities and civil society in combating corruption in the period up to 2014 approved by the decision of the Presidium of the Presidential Council of the Russian Federation for Anti-Corruption (paragraph 2 of section 1 of Protocol No. 34 of 25.09.2012). Available at: http://minjust.ru/node/5149 (accessed on January 23, 2016).

Declarator. Available at: http://declarator.org/ (accessed on January 23, 2016)

Efimov, O. (2011) Disfunction of the mediatization of civil activity. Personality. Culture. Society. Edition 4, 67-68 (13), 184-191.

EPAC/EACN ANTI-CORRUPTION AUTHORITY (ACA) STANDARDS: Adopted November 2011. Available at: http://www.epac.at/downloads/recommendations/doc_view/1-anti-corruptionauthority-standards (accessed on January 13, 2016).

The Federal Law No. 172-FZ "On anti-corruption expertise of regulatory legal acts and draft normative legal acts" dated 17.07.2009, In Russian Newspaper, July, 22, 2009.

The first anti-corruption media. Available at: http://pasmi.ru/ (accessed on January 23, 2016).

"For honest procurement". Available at: http://zachestnyezakupki.onf.ru/ (accessed on January 23, 2016).

Kabanov, P. (2012) Some ways of interactions between the institutions of civil society and local governments in the sphere of combating corruption. In Administrative and municipal law, (5), 5-8.

Khlonova, N.V. (2013). Messages corruption offenses: prospects for improving the view of foreign experience. In Actual problems of economics and law, 25 (1), 272-279.

Krasnousov, S.D. (2011). Russian commerce and industry chamber as the institute of civil society in system of prevention of corruption. In Theory and practice of social development, (8), 24 -243.

Navalnyi: the "RosPil" incident - pressure on the Internet. Available at: http://www.bbc. co.uk/russian/russia/2011/05/110503_navalny_incident_comments.shtml (accessed on January 23, 2016).

Okhotskiy, I. (2012). The principles of anti-corruption strategy and ways of their implementation. In Law and governance of the XXI century, (4), 86-95.

Rogovaia, A.V. (2013). Implementation Issues Concept interaction of state authorities, local Government and civil society in the field of combating corruption. In The Monitoring of Law Enforcement Journal, (4), 21-28.

"RosPil”: official web-page. Available at: http://rospil.info/ (accessed on January 23, 2016).

Russian Political Party "People Against Corruption". Available at: http://party-npk.ru/ (accessed on January 23, 2016).

Samarucha A.V. (2015). Corruption Crimes: determination issues and its influence on the socioeconomic development of regions. In Criminology Journal of Baikal National University of Economics and Law, 9 (1), 57 - 67.

Schedrin, N.V. (2013). On the Principles for Countering Corruption. In Actual problems of economics and law, (1), 280-284.

Tereshkova, V.V. (2015). Comparative analysis of successful practices of corruption counteraction in the sphere of school education in foreign countries. In Actual problems of economics and law, (1), 253-262.

To a question on the activities of the Council (2010), Available at: http://www.korupcii.net/index. php?s=4\&id=62 (accessed on January 23, 2016). 
United Nations Convention against Corruption: Adopted by General Assembly resolution 58/4 of 31 October 2003. Available at: General Assembly resolution 58/4 of 31 October 2003 (accessed 23 January 2016).

\title{
Механизмы взаимодействия государства \\ и гражданского общества \\ в сфере антикоррупционной деятельности \\ в свете имплементации статьи 13 Конвенции ООН \\ против коррупции в российское законодательство
}

\author{
А.В. Путинцев, Т.Ч. Шаракшинова \\ Байкальский государственный университет \\ Россия, 664003, Иркутск, ул. Ленина, 11
}

\begin{abstract}
В статье анализируется механизм взаимодействия государства и гражданского общества в прочессе имплементации статьи 13 Конвенции ООН против коррупции. Авторы рассматривают некоторые тенденции правового регулирования в антикоррупционной сфере, антикоррупционные инициативы гражданского общества. Исследование содержит предложения по повышению эффективности имплементации норм статьи 13 Конвенции ООН против коррупиии в российское законодательство.
\end{abstract}

Ключевые слова: коррупиия, гражданское общество, прозрачность, защита заявителей о фактах коррупиии.

Научная специальность: 12.00.00 - юридические науки. 